\title{
Проблема прав на минеральные ресурсы (сравнение международного и российского права)
}

\section{Сиражетдинова-Гуреева О.А.*}

«Земля и другие природные ресурсы используются и охраняются в Российской Федерации как основа жизни и деятельности народов, проживающих на соответствующей территории», - сказано в Конституции РФ (п. 1 ст. 9). В этом общем конституционном установлении подчеркнуты фундаментальная значимость вопросов правового режима природных ресурсов как главного богатства страны, повышенные требования к разработке такого режима с учетом интересов как нынешнего так и грядущих поколений народов России. Экономические и правовые реформы, связанные с рыночными преобразованиями в России, сказались на правовом режиме ее природных ресурсов. Эти реформы востребовали обновление роли государства в управлении природными ресурсами, в том числе морскими ${ }^{1}$.

Ключевая альтернатива: вещного права собственности на минеральные ресурсы in situ нет; есть лишь публично-правовой режим таких ресурсов, определяемый по международному праву и по российскому законодательству; вторая альтернатива: право собственности на такие ресурсы - реальность.

Но и при втором подходе надо признать, что отсутствие четкого правового регулирования статуса федеральных природных ресурсов, а также складываюшихся в горнодобываюших регионах земельных отношений создало сложную юридическую ситуацию для субъектов федерации ${ }^{2}$. Серьезная, хотя и не совсем удачная попытка урегулировать в Законе этот, а также некоторые другие ключевые вопросы горного дела была предпринята при разработке Закона Российской Феде-

\footnotetext{
- Сиражетдинова-Гуреева Ольга Александровна - научный сотрудник Совета по.изучению пронзводительных сил при Президиуме РАН.

' А.Н. Вылегжанин. «К характеристике правового режима морских природных ресурсов России» // Государство и право. 1997. № 7. С. 49-59.

? Российское горное законодательство (документы и комментарии) / АЕН РФ, Независимый юридический центр «Рес-лекс», Гос. компания «Росуголь». М.: Недра, 1996. $414 \mathrm{c}$.
} 
рации «О внесении изменений и дополнений в Закон Российской Федерации «О недрах», принятого в 1995 г. В настоящий момент законодателями разрабатывается и вовсе новая концепция горного права, выражающаяся в создании Горного кодекса РФ.

В проблеме собственности в сфере недропользования можно выделить три компонента: право собственности на недра, соотношение права собственности на недра и земельные участки над ними, право собственности на добытые полезные ископаемые. Основными актами, регулируюшими эти вопросы, являются Конституция РФ, Гражданский кодекс РФ, Закон «О внесении изменений и дополнений в Закон Российской Федерации «О недрах» 1995 г., Земельный кодекс РФ 2001 г.

Согласно Конституции Российской Федерации, земля и другие природные ресурсы могут находиться в частной, государственной, муниципальной и иных формах собственности (ст. 9). В первой части Гражданского кодекса Российской Федерации, введенной в действие 1 января 1995 года, предусматривается, что земельные участки и участки недр относятся к недвижимым вещам, являющимся объектом гражданских прав. В ст. 214 «Право государственной собственности» записано: «Земля и другие природные ресурсы, не находящиеся в собственности граждан, юридических лиц либо муниципальных образований, являются государственной собственностью». Таким образом, на наш взгляд, подтверждается, что участки земли и недр могут находиться в частной собственности. Согласно Закону «О внесений изменений и дополнений в Закон Российской Федерации «О недрах» от 3 марта 1995 года, «недра в границах территории Российской Федерации, включая подземное пространство и содержащиеся в недрах полезные ископаемые, энергетические и иные ресурсы, являются государственной собственностью». На наш взгляд, это положение не соответствует Конституции РФ 1993 г., предусматривающей возможность различных форм собственности на природные ресурсы.

Вместе с тем Гражданский кодекс РФ допускает установление ограничений в обороте определенных в законодательном порядке объектов гражданских прав. Так, в ст. 129 «Оборотоспособность объектов гражданских прав» говорится, что земля и другие природные ресурсы могут отчуждаться или переходить от одного лица к другому иными способами в той мере, в какой их оборот допускается законами о земле и других природных ресурсах. В этом смыс- 
ле вряд ли можно считать соответствуюшим Гражданскому кодексу установленный в Законе «О недрах» тотальный запрет на любые сделки с участками недр. Так, согласно этому закону, участки недр не могут быть предметом купли, продажи, дарения, наследования, вклада, залога или отчуждения в иной форме. В то же время вполне правомерно установление определенных правил и введение ограничений на пользование и распоряжение недрами. В соответствии с Законом права пользования недрами могут отчуждаться или переходить от одного лица к другому в той мере, в какой их оборот допускается федеральными законами (ст. 1-2).

В соответствии с Законом «О недрах» пользователями недр могут быть субъекты предпринимательской деятельности, независимо от форм собственности, лица и граждане других государств, в том числе юридические, если законодательством Российской Федерации и законодательством ее субъектов они наделены правом заниматься соответствующим видом деятельности при пользовании недрами.

Права и обязанности пользователя недр возникают на основе и с момента получения лицензии (без лицензии возможна добыча собственником земельного участка лишь обшераспространенных полезных ископаемых). Добытые полезные ископаемые и иные ресурсы по условиям лицензии могут находиться в федеральной государственной собственности, собственности субъектов Федерации, муниципальной, частной и в иных формах собственности. В действуюшем законодательстве вопрос о праве на добытые полезные ископаемые решается только между двумя сторонами - государством и инвестором-пользователем. Имеется в виду Указ Президента Российской Федерации от 24 декабря 1993 года. «Вопросы соглашений о разделе продукции при пользовании недрами». Согласно этому Указу, соглашение о разделе гродукции является одной из форм договорных отношений государства с инвесторами - пользователями недр, которая предусматривает раздел добытого минерального сырья между договаривающимися сторонами. В трактовке этого документа государством является Российская Федерация в лице Правительства РФ и органа исполнительной власти субъекта Российской Федерации, на территории которого расположен участок недр, или уполномоченных ими органов, а инвестором - юридическое лицо или группа юридических лиц (п. 2).

При этом Закон РФ «О недрах» не предусматривает обязательное возникновение права собственности недропользователя на добытое 
полезное ископаемое в случае отсутствия этого условия в лицензии ${ }^{3}$. Следуя положениям ст. 1-2 указанного Закона, добытые полезные ископаемые могут находиться в различных формах собственности (частной, государственной, муниципальной). При отсутствии данного условия в лицензии на право пользования недрами возникают резонные вопросы: перешло ли в этом случае право собственности на полезное ископаемое от государства к недропользователю? Если да, то в какой момент и в каком объеме?

Пункт 5 ст. 9 Закона «О недрах» говорит только, что «права и обязанности пользователя недр возникают с момента государственной регистрации лицензии на пользование участками недр, при предоставлении права пользования недрами на условиях соглашения о разделе продукции с момента вступления такого соглашения в силу», но момент передачи прав собственности не обозначен. Так, еще 26 сентября 2002 года на региональной конференции «Федеральное законодательство и перспективы развития нефтегазового комплекса», которая состоялась в г. Ханты-Мансийск, единогласно была принята резолюция «П. 8. Внести отдельную главу в Закон РФ «О недрах», где предусмотреть вопросы перехода права собственности на добываемые полезные ископаемые от Государства к недропользователю в процессе добычи», но до сих пор этот вопрос не урегулирован.

В такой правовой среде нет ясных юридических ориентиров для урегулирования коллизии права собственности на недра и права собственности на земельный участок с правами пользователя недр и собственника земельного участка. Отсутствие «горизонтальных» связей между горным и земельным, горным и природоохранным правом свидетельствует об укоренившейся в российском законотворчестве традиции, при которой каждое ведомство разрабатывает законодательное регулирование «под себя», заранее оставляя простор для ведомственных приказов и инструкций. Отсутствие разработанного правового определения федеральной собственности, в частности, в значительной мере тормозит формирование целостной системы правового регулирования эксплуатации ресурсов континентального шельфа. Низок юридический и технический уровень значительного числа ведомственных нормативных актов. В качестве иллюстрации достаточно привести один пример: 14 действующих нормативных актов посвящены

3 О некоторых вопросах права собственности на недра и полезные ископаемые. В.Д. Мельгунов (ЗАО «Юридическое агентство «Ноланд консалтинг»"). 2002. 
лицензированию в горном деле. При чтении их складывается впечатление, что авторы последующего акта не читали не только предшествующие акты, но и не знакомы ни с Гражданским кодексом, ни с законодательством об окружаюшей среде и уж тем более с зарубежным горным законодательством.

По мнению отечественного цивилиста Е.А. Суханова, «содержание права собственности на землю и другие природные ресурсы» имеет особенности. Возможность иметь их в собственности «предполагает и возможность их перехода от одних собственников к другим... Однако этот оборот законодательно ограничен (п. 5 ст. 129 ГК) в общественных, публичных интересах, так же как и содержание прав всякого землепользователя или природопользователя. Ведь количество и состав такого рода объектов ограничены в силу очевидных объективных причин, а их использование всегда поэтому так или иначе затрагивает интересы общества в целом. Поэтому и свободное, по усмотрению собственника, использование принадлежащих ему правомочий относительно земельных участков и иных природных объектов подвергается неизбежным ограничениям в публичных интересах, причем во всяком правопорядке. Так, собственник должен учитывать природоохранные (экологические) требования и запреты, целевое назначение данных объектов, требование закона по их рациональному использованию, права и интересы соседствующих пользователей и т.д. Это является не ограничением его права собственности, а установлением более точных границ его содержания, которое в любом случае не может быть беспредельным» ${ }^{4}$.

Добавим, что об особенностях содержания права собственности на природные ресурсы свидетельствуют и другие положения ГК РФ. ГК не относит «природные ресурсы» к «имуществу». В п. 1, 2 и 4 ст. 209 («Содержание права собственности») предусмотрены права собственника на имущество, а в п. 3 этой же статьи - права собственника природных ресурсов, т.е. п. 3 (о праве собственности на природные ресурсы) следует рассматривать как lex specialis (специальное правило). В таком же качестве надо воспринимать п. 2 ст. 214 ГК РФ («Право государственной собственности»), в котором природные ресурсы отнесены к государственной собственности. Режим природных ресурсов ГК РФ не отождествлен с режимом имушества, находяшегося в государственной собственности (п. 1, 4 и 5 этой же статьи).

${ }^{4}$ Суханов Е.А. Право собственности в Гражданском кодексе // Закон. 1995. № 11. С. 24. 


\section{Вопрос о правах на морские минеральные ресурсы}

В прошлом, в условиях господства общественной собственности на средства производства, государство выполняло: а) функции собственника как морских природных ресурсов, так и большинства морехозяйственных объектов (береговой инфраструктуры, морских судов и т.п.) и б) функции по сути монопольного творца национального права, в том числе в сфере использования морских ресурсов и пространств. Сегодня же субъектов права собственности на морехозяйственные объекты стало множество, а вопрос о разграничении между Российской Федерацией и приморскими субъектами федерации прав на морские природные ресурсы в пределах государственной территории не урегулирован. Соотношение норм договора между лицами (юридическими, физическими) и норм гражданского законодательства изменилось, и государство уже не является господствующим творцом гражданско-правовых правил поведения. Отсутствие разработанного правового режима использования природных ресурсов территориального моря, экономической зоны, континентального шельфа РФ сегодня становится недопустимым: нет такого режима - ergo, есть утечка ресурсов, причем не из одного кармана государства в другой, а из государственной собственности в иную, например в частную, в собственность иностранных компаний.

Что касается вопросов разведки и разработки природных ресурсов морского дна за пределами территориальных вод, то решение таких вопросов в 1950 г. было предложено возложить на ООН. В 1957 г. Комиссия по изучению организации мира предложила, чтобы Генеральная Ассамблея ООН провозгласила морское дно за пределами национальной юрисдикции «собственностью международного сообщества». В 1966 г. Комиссия предложила учредить Агентство ООН по морским ресурсам, которое должно было бы «управлять международными ресурсами; осуществлять права собственности».

Вопрос о применимости права собственности на морские пространства и ресурсы исследовался и в отечественной экономической науке. «Ни в какие времена, при любых общественных отношениях, никогда ни в какой форме не было собственности на Мировой океан. Никто и никогда ранее не владел ни им, ни его частями, ни его ресурсами, ни пространствами», - пишет Г.К. Войтоловскийб. Американский уче-

${ }^{5}$ А.Н. Вылегжанин. «К характеристике правового режима морских природных ресурсов России» // Государство и право. 1997. № 7. С. 49-59.

' Войтоловский Г.К. Стратегия рыболовства. М., 1988. С. 48-49. 
ный Е.А. Кин (Государственный университет Сан-Диего) считает, что В отношении прибрежных минеральных ресурсов изначальный собственник известен - государство. Таким образом, установление национальным законодательством права собственности на морские минеральные ресурсы в пределах государственной территории под сомнение не ставится. Однако такое право реализуется в порядке, установленном законами данного государства, принятыми в соответствии с международным правом.

В отличие от морских пространств, морские минеральные ресурсы в пределах государственной территории, бесспорно, могут быть объектом права собственности, хотя реализация этого права специально регламентируется законом. Действующая Конституция РФ применяет понятие «собственность» при установлении начал правового режима природных ресурсов (ст. 9). Далее, согласно ст. 36 Конституции, владение, пользование, распоряжение «природными ресурсами осушествляется их собственниками свободно, если это не наносит ущерба окружаюшей среде и не нарушает прав и законных интересов иных лиц». ГК РФ также не запрещает право собственности на природные ресурсы, если такое право допускается законами о природных ресурсах. Ограничительных для прибрежного государства норм о природных ресурсах его территориального моря и уж тем более внутренних морских вод международным правом не предусмотрено. Государство, следовательно, вправе передать такие ресурсы в муниципальную или частную собственность.

К режиму минеральных ресурсов территориального моря России применима ст. 9 Конституции: такие ресурсы могут находиться в частной и муниципальной собственности. Могут, но в настоящее время не находятся: нет пока юридически безупречных прецедентов передачи государством в частную или муниципальную собственность природных ресурсов территориального моря. Природные ресурсы территориального моря РФ законодательством отнесены в настоящее время только к государственной собственности.

Установление законом государственной собственности на природные ресурсы, в том числе морские, в пределах государственных границ РФ не отвечает, однако, на ключевой для ресурсопользователя вопрос: кто выступает в России от имени собственника морских природных ресурсов?

Согласно ст. 67 Конституции «территория Российской Федерации включает в себя территории ее субъектов, внутренние воды и терри- 
ториальное море, воздушное пространство над ними». Территорня субъекта федерации, следовательно, не включает внутренние воды, территориальное море РФ, воздушное пространство. Она определена административными границами. Вопросы владения, пользования, распоряжения природными ресурсами в границах субъекта федерации отнесены к совместному ведению федерации и соответствующего субъекта федерации (ст. 72 Конституции РФ).

Понятие «совместное ведение» Конституцией не определено, хотя по тексту ее ясно, что понятие «ведение» не равнозначно понятию «собственность»: согласно этой же статье, «разграничение государственной собственности» отнесено к «совместному ведению» федерации и субъектов федерации. Конституционная формула о «совместном ведении» (т.е. об установлении режима управления природными ресурсами сообща федерацией и данным субъектом) реализуется прежде всего путем заключения между федерацией и соответствуюшим субъектом федерации договоров о разграничении предметов ведения. Надо сказать, однако, что обязанность выделить федеральную собственность на природные ресурсы из государственной собственности действующей Конституцией РФ не предусмотрена.

Значительно четче и в полном соответствии с международным правом в российском законодательстве решен вопрос о правах на минеральные ресурсы экономической зоны и континентального шельфа РФ.

Конституция РФ (ст. 71) относит к ведению федерации определение статуса и защиту исключительной экономической зоны и континентального шельфа РФ. Права России в отношении минеральных ресурсов экономической зоны и континентального шельфа реализуются только федеральными органами власти, как и в других прибрежных государствах-федерациях?

\section{Характеристика права собственности на недра в странах Западной Европы и Америки}

Во многих таких странах закрепляется, как и в нашей стране, право государственной собственности на недра с вытекающим отсюда порядком предоставления недр и зашиты права государственной собственности. Четко урегулированы вопросы права собственности на недра

${ }^{7}$ А.Н. Вылегжанин. «К характеристике правового режима морских природных ресурсов России» // Государство и право. 1997. № 7. С. 49-59. 
федерации и ее субъектов. Следует отметить и высокий уровень защиты прав и интересов собственников, владельцев и пользователей недрами ${ }^{8}$.

Отношения собственности на участки недр и месторождения полезных ископаемых в недрах, правовой режим недр занимают главенствующее положение в системе горных отношений и тесно связаны с такими правовыми категориями гражданского и горного права, как право собственности, вещное право, имущественное право (прежде всего право на недвижимое имущество).

Как пишет профессор Е.А. Суханов, «в большинстве известных гражданско-правовых систем само право собственности обычно рассматривается как разновндность вешных прав или как наиболее широкое по содержанию вешное право, опосредующее «хозяйственное господство лица над вещью» (имуществом)»9.

В горном праве собственниками и арендаторами вешные права недропользователей реализуются в виде прав пользования предоставленными им участками недр и месторождениями полезных ископаемых. Во многих рассматриваемых нами странах горное законодательство содержит развернутую регламентацию вещных прав по использованию участков недр, содержащих месторождения полезных ископаемых.

Возникновение вещных прав предопределено существованием таких крупных собственников природных ресурсов, как государство и его субъекты, которые либо сами создают самостоятельные организации с правами юридических лиц, либо передают участки как государственную собственность для самостоятельного пользования юридическим и физическим лицам.

Приобретая подобные вешные права, недропользователи по своему усмотрению совершают в отношении участков недр любые действия, не противоречащие закону. При этом грани между объемом правомочий собственника и обладателя рассматриваемых вещных прав столь незначительны, что трудно провести различие между ними. Нередко и сами правовые формулировки, применяемые для регулирования отношений вешного права, не отличаются от применяемых к регулированию отношений собственности.

${ }^{8}$ Б.Д. Клюкин. Горные отношения в странах Западной Европы и Америки. М.: Городец-издат, $2000.443 \mathrm{c}$.

${ }^{9}$ Гражданское право. В 2-х томах / Под ред. Е.А. Суханова. Т. 1. М.: БЕК, 1993. С. 284. 
В системе западного права право на недра выступает составной частью частного права и относится к вешному праву. Особенностью вещного права, имеющей существенное значение для недропользования, является возможность оборотоспособности участков недр, необходимость регистрации сделок с ними, разрешительный характер пользования этой собственностью и разрешительный характер сделок, совершаемых по поводу участков недр и требующих соблюдения специальных разрешительных процедур.

Доминирующее положение в системе современных горных отношений занимает институт права собственности, детально разработанный в горном и гражданском праве и детально урегулированный в законодательстве. На его основе урегулированы отношения по поводу владения, пользования и распоряжения недрами, полезными ископаемыми, самим горным предприятием как комплексом, добытыми полезными ископаемыми и пр. Свое утверждение он начал в период первых буржуазных революций с провозглашения абсолютного характера собственности. Характерным примером выражения такого абсолютного характера собственности является французское законодательство. В ст. 544 Гражданского кодекса Франции сказано, что «собственность есть право пользоваться и распоряжаться вещами наиболее абсолютным образом с тем, чтобы пользование не являлось таким, которое запрещено законом». К недвижимой собственности, например, во французском законодательстве «по их природе» относятся недра как присоединенные к земельному участку, а также здания и сооружения, обслуживающие горнорудное производство (ст. 517, 518).

Вместе с тем абсолютный характер права собственности существенно ограничивается издаваемыми в настоящее время законами. Такое ограничение прежде всего проистекает из положений о том, что право собственности является предметом гарантий и ограничений, содержащихся в конституциях, и о том, что это право устанавливается в интересах общественного блага.

В современном гражданском праве, особенно в последнее столетие, в качестве ограничителя прав собственности важнейшим фактором стал выступать социальный характер и социальная значимость собственности. С признанием этого фактора родилась и стала развиваться концепция функциональной собственности применительно к участкам недр. Для определения функциональной характеристики собственности важное значение имеет то, что собственность используется не для 
личного пользования, а для производства продукции или предпринимательской деятельности ${ }^{10}$. Право собственности перестает быть нейтральным к характеру использования частной собственности. В континентальном и англосаксонском праве оно четко стало разделять личную собственность и экономическую (или производственную) собственность.

При таком делении собственник в первом случае не ограничен В распоряжении личной собственностью, а во втором существенно ограничивается законодательством в зависимости от того, какие экономические или общественные функции выполняет его собственность. Главным становится социальное предназначение собственности. При этом объем ограничений определяется, как правило, тем, насколько общество зависит от этой собственности, и от того, какую функцию она выполняет.

По англосаксонскому и французскому праву такие ограничения прав собственности распространяются прежде всего на земельные участки и участки недр, месторождения полезных ископаемых, реже на сами недра; по германскому горному праву - на земельные участки, предоставляемые для недропользования.

Происходящие в XX в. общественные и экономические преобразования, приведшие к многочисленным ограничениям права собственности и возложению на собственность социальных функций, усиление роли государства изменили ее характер и постепенно преобразуют институт собственности частного права путем установления ограничений в его использовании в институт собственности публичного права.

Что касается законодательного закрепления и содержания прав собственности в отдельных странах, оно чрезвычайно разнообразно. В $Ф Р Г$ горное законодательство ориентируется на конституционное определение права собственности, данное в ст. 14 Основного закона, где говорится, что «содержание собственности определяется законом», и на цивилистическое определение, данное в 903 ГГУ. Таким образом, в ФРГ проблема собственности и ее гарантии относится как к конституционному, так и к гражданскому и горному праву. В конституционном законодательстве ФРГ права собственности обеспечиваются через основные права человека, что вытекает из конституционных

\footnotetext{
${ }^{10}$ Б.Д. Клюкин. Горные отношения в странах Западной Европы и Америки. М.: Городец-издат, 2000. 443 с.
} 
положений, а в гражданско-правовом и горном законодательстве через утверждение права собственности как института.

Оценивая нормы ГГУ и Горного кодекса 1980 г., следует отметить, что в них значительное внимание уделяется не только регулированию прав собственности, но и установлению гарантий имущественного положения собственника прежде всего от неправомерного государственного вмешательства (в таких случаях собственник недр вправе потребовать: возмещения ущерба, возвращения изъятой собственности, денежной компенсации в случае несоответствуюшего определения размера возмещения, изменения определения содержания ограничений прав или ликвидации неправомерного вмешательства).

Почти во всех рассматриваемых нами странах доминирующее положение занимает право государственной собственности на недра. Во Франции собственником недр является государство. Бесспорным является право государства на недра на земельных участках, находящихся в государственной собственности. В силу ст. 537 и 538 французского Гражданского кодекса участок земли, не предоставленный в собственность и не освоенный кем-либо, рассматривается как государственная собственность (domain public). В соответствии с приведенным нами законом 1919 г, а затем изданием Горного кодекса Франции 1956 г. право распоряжения недрами полностью перешло в руки государства.

В CWIA около $1 / 3$ территории страны занимают земли с полезными ископаемыми, находяшиеся под юрисдикцией федеральных властей и подконтрольные Конгрессу США. В Канаде основные богатства недр также находятся в руках либо Короны, либо провинций и территорий. В ФРГ федеральное законодательство делит полезные ископаемые на открытые для поисков и разработок, и полезные ископаемые, входящие в состав земельной собственности. Полезные ископаемые, открытые для понсков и добычи, в большинстве своем находятся в собственности государства. Таким образом, значительная доля участков недр, содержащих полезные ископаемые, находится в государственной собственности.

Что касается в целом картины распределения прав собственности на участки недр, то по отношению к той или иной форме собственности на недра зарубежные страны могут быть подразделены на три группы:

1) в одних странах право государственной собственности на недра 
признано и закреплено законом (Аргентина, Бразилия, Мексика, Перу, Чили и др.);

2) в других - право государственной собственности на недра распространяется только на земельные участки, находящиеся в государственной собственности (федерации или ее субъекта), допускается частная собственность на участки недр и месторождения полезных ископаемых, но на любых земельных участках только государственным органам принадлежит право давать разрешение на разведку и эксплуатацию недр специальным субъектам предпринимательской деятельности (Франция, ФРГ, Япония и др.);

3) наконец, в третьей группе стран (Англия, отдельные штаты США, Канада) вместе с государственной собственностью существует право частной собственности на земельный участок, что предполагает и право собственности на полезные ископаемые, расположенные под этим участком. В большинстве случаев в этой ситуации допускается признание самостоятельных прав на земельный участок и участок недр и допускаются сделки отдельно в отношении прав на земельный участок и участок недр под ним.

При всем многообразии специфических черт для определения права собственности на недра большое значение имеют тесная связь права собственности на недра с правом собственности на поверхность земли и правовой режим земельных участков, выделяемых для недропользования, и даже способ ведения горных работ.

Во Франции сохранился основной наполеоновский принцип - государство является собственником недр, а не собственником земли. Недра отделены от земли. Они не могут быть присвоены частным лицом. Однако правительство вправе предоставить для недропользования концессию либо горный отвод с титулом владения. Любая передача горной собственности во Франции требует согласия властей.

Горный кодекс распространяет свое действие и регулирует только отношения, связанные с полезными ископаемыми, находящимися в естественном состоянии и не поднятыми на поверхность. На добытые полезные ископаемые устанавливается частная собственность, и отношения здесь регулируются в основном на базе гражданскоправовых норм. Все споры решаются в исковом порядке.

Горный кодекс Франции исходит из того, что в большинстве основных районов месторождения пфлезных ископаемых являются государственной собственностью. Большинство полезных ископаемых 
по французскому законодательству национализировано, прежде всего это относится к горючим полезным ископаемым (каменный уголь, углеводороды), на которые распространяется публичный порядок регулирования.

В Германском гражданском уложении (ГГУ), являющемся образцом кодифицированного европейского права, оказавшего сушественное влияние на формирование и развитие системы российского гражданского законодательства, в ст. 905 установлено: «Право собственника земельного участка распространяется как на пространство, находящееся над поверхностью, так и на недра земли»" ции ГГУ четко прослеживается рецепция римского права о соединении земельного участка и всего, что находится на нем и под ним, включая полезные ископаемые.

Полезные ископаемые, входяшие в земельную собственность, являются собственностью землевладельца. Владение земельным участком не распространяется на полезные ископаемые, объявленные свободными для поисков и разработок.

Государственная собственность на некоторые виды ископаемых существует и расширяется также в тех странах, где земельный собственник обладает и правом на недра.

Так, согласно английскому общему праву, недра (месторождения полезных ископаемых) признаются частью, «парцеллой» земли, и собственник участка рассматривается как собственник расположенных под поверхностью недр и всего их содержимого «вплоть до центра земного шара» (судебный прецедент 1843 г.). Однако еще прецедентом 1567 г. было установлено, что собственностью Короны являются золото и серебро. Законами последних десятилетий о нефти, о национализации угольной промышленности, об атомной энергии такой же собственностью признаны нефть, газ, уголь и расщепляющиеся материалы.

По английскому праву полезные ископаемые являются собственностью землевладельца. Однако эта общая посылка имеет массу исключений и ограничений. Недра шельфа принадлежат по праву Короне. Урановые месторождения принадлежат государству, и управляет ими по Закону 1938 г. Государственный секретарь. Значительные изменения произошли в правах собственности в связи с национализацией угольной промышленности Англии в 1946 г. В результате ряда пре-

"Германское право. Ч. 1. М.: Международный центр финансово-экономического развития, 1996. С. 206. 
образований Национальный угольный совет получил права собственности на все угольные шахты.

Собственность на недра и право на углеводороды на публичных землях в Канаде находятся в руках правительств провинции. Федеральное правительство имеет право на углеводороды лишь в северо-западной части Юкона и в пределах индейских резерватов и национальных парков. Канадский континентальный шельф, хотя и объявлен собственностью Короны, однако право на него оспаривается провинциями и территориями, а кроме них и правительством США.

Для регулирования отношений по использованию месторождений нефти, которая признана ценным полезным ископаемым, канадское правительство 30 июля 1975 года создало государственную национальную корпорацию Короны "Реtro Canada". Корпорация получила право проводить изыскания и добычу углеводородов, развивать нефтегазовые ресурсы страны, вести поиски углеводородов, участвовать в производстве, распределении, очистке и маркетинге топлива, вести переговоры относительно приобретения за границей нефтепродуктов, необходимых для поддержания канадских запасов поставками из-за рубежа.

Важным обстоятельством было введение в эти годы правила о сохранении $25 \%$-ного государственного участия в нефтяном производстве и не менее 50\%-ной доли в частных нефте- и газодобывающих иностранных фирмах. Эти меры привели к получению федеральным министром энергетики обширных контрольных полномочий в одобрении поисковых соглашений на федеральных землях.

В $C W A$ действует тот же принцип английского общего права, однако национализация там не проводилась и фактическое положение несколько иное, поскольку имеется довольно много земель, не находяшихся в частной собственности.

Право государственной (федеральной) собственности распространяется на все свободные земли Соединенных Штатов, включая Аляску. Государственные земли, представляюшие ценность с точки зрения содержашихся в них полезных ископаемых, не подлежат продаже.

Помимо земель, находящихся в федеральной собственности, часть земель в США принадлежит штатам. Это земли, переданные штатам актами Конгресса, как правило, без каких-либо специальных оговорок относительно режима недр. Правовое регулирование пользования недрами в штатах строится обычно по принципам федерального законодательства или законодательства штатов. 
Право государственной собственности на недра по сушеству является в США номинальным, так как частным компаниям предоставляется полная свобода разведки ископаемых на государственных землях и приобретения в собственность или на началах аренды участков, на которых обнаружены месторождения.

Федеральными государственными землями являются земли, тем или иным способом приобретенные правительством США.

В законодательстве США предусматривается приоритет законов федерации перед законами штатов. Законодательство штатов выступает как инструмент детализации и конкретизации предписаний федеральных органов. Конгресс США как высший законодательный орган обладает правом принимать законодательные акты, составляющие основу правового регулирования горных отношений. Он также вправе отчуждать частные земли для предоставления их недропользователям, определять расходы и устанавливать налоги в области недропользования.

Титул на участок утверждается патентом, в котором указываются права в отношении поверхности и недр.

Земли федерации составляют в США около 1/3 земельной территорици страны, а в отдельных штатах - от 60 до $90 \%$ их территории. На этих территориях допускается поиск и добыча на основе патентов. Правительство США имеет право изымать земли федерального значения из открытого доступа для разведки и разработки, создания федеральных резервов.

Частное землевладение является предметом регулирования федерации и штатов, особенно с точки зрения управления отношениями собственности, регулирования сделок с землей, а также охраны окружающей среды, налогообложения, страхования, зонирования, отнесенных законодателем к компетенции и федеральных властей, и властей штатов. Условия недропользования на этих землях определяются договором между собственником земли и недропользователем.

США - одна из немногих стран, где частный собственник может получить титул собственника на минеральные ресурсы. Титул на месторождение полезного ископаемого может быть частью титула на земельный участок или самостоятельным. В отличие от правовых систем большинства стран недра - часть земельного участка, если не отъединены от него. Первоначальный суверенный собственник, будь то федерация или штаты, может передавать недра вместе с земельным участком или отдельно от него любым субъектам, в том числе и част- 
ным собственникам (за исключением прежде всего федеральных земель), то есть тот, кто эксплуатирует шахту, рудник, добывает нефть или газ, может приобрести право на добычу полезных ископаемых на данном земельном участке. Земельный участок выступает здесь атрибутом приобретенной собственности, на которую распространяются правомочия собственника - включая право продать либо заложить его. Эта собственность, хотя и подчиняется нормам административного права органов управления (policy power), в то же самое время подпадает под конституционную защиту от причинения вреда действиями федеральных и штатных властей, как и любая другая частная собственность.

Вопросы собственности на месторождения полезных ископаемых являются одними из сложнейших в зарубежном горном законодательстве. Как мы видим, государственная собственность на недра устраивает сейчас не только страны с континентальной системой права, но и страны англосаксонской системы, где не наблюдаются оживленные дискуссии об изъятии земель из федерального ведения. Практически же США уже выкупают в значительных размерах потенциально богатые важными полезными ископаемыми (особенно стратегическими) земли в федеральную собственность.

В Англии и части штатов США традиционно сложилось право частной собственности не только на земельные участки, содержащие полезные ископаемые, но и право частной собственности на недра под этими земельными участками.

Право собственности на недвижимость (real property), к которой относятся земельные участки, участки недр, шахтные сооружения и другая недвижимость, в англосаксонском праве базируется на понятии freehold - свободном, полноправном и безусловном праве собственности на недвижимость.

Имеются три основных типа freehold estate: fee simple - право собственности за простую плату, fee tail - заповедное имущество и life estate - пожизненная собственность ${ }^{12}$.

Помимо института права собственности на развитие горных отношений сушественное влияние оказывают иные вещные права, проявляюшиеся в реализации экономических отношений собственности, аренда, залог и др. В отличие от права собственности, предоставляю-

'2 Б.Д. Клюкин. Горные отношения в странах Западной Европы и Америки. М.: Городец-издат, 2000. $443 \mathrm{c}$. 
шего обладателям полную хозяйственную свободу в использовании своего имущества, эти права называются ограниченными, ибо не могут совпадать с правами и возможностями собственника ${ }^{13}$.

\section{Рентные механизмы как форма реализации прав собственника}

Рента - (от немецкого слова rente - доход) в первоначальном, наиболее распространенном своем значении обозначала доход землевладельца в форме земельной ренты со сдаваемого в аренду земельного участка или доход, получаемый рантье, в виде процента с предоставляемого в ссуду капитала.

Рента как доход землевладельца привлекала к себе внимание экономистов с давних времен ${ }^{14}$. С конца XVIII столетия проблема ренты попадает в центр внимания английской политической экономии: Адам Смит (в его труде «Исследование о природе и причинах богатств народов» содержится глава "О ренте с земли»), а затем и всей Европы: Дж. Андерсон, Джеймс Стюарт, И.Г. Буш и т.д. Наконец, Д. Рикардо, обладая строгим математическим умом и банкирским расчетом, прйдал теории ренты строгость и точность. В книге «Принципы политической экономии и налогообложения» (1817) в главе II «О ренте» Рикардо определяет ренту как долю продукта земли, которая уплачивается землевладельшу за пользование первоначальными и неразрушимыми силами почвы. Исходя из этого, Рикардо приходит к выводу, что «рента платится за пользование землей только потому, что количество земли не беспредельно, а качество ее неодинаково». С ростом населения в стране под обработку попадают худшие земли или земли, расположенные менее удобно. Когда под обработку попадают земли второго разряда, то на земле первого тотчас возникает рента, которая будет зависеть от различия в качестве этих двух участков, т.е. он определил понятие ренты как дифренты - дохода, превышающего среднюю прибыль вследствие относительно лучших условий приложения капитала.

Федеральным законом от 8 августа 2001 года № 126-Ф3 часть вторая Налогового кодекса РФ дополнена главой 26 «Налог на добычу полезных ископаемых» вследствие чего произошел некоторый отход

\footnotetext{
${ }^{13}$ Гражданское право. Т. І. С. 283.

${ }^{14}$ Матвеев Ю.Ф., Субботин М.А. Рентный подход в недропользовании. М.: НИА-Природа, 2003. $244 \mathrm{c}$.
} 
от декларированных и экономически целесообразных рентных подходов в недропользовании, т.е. рента в понимании Рикардо была ликвидирована. Все большее число специалистов и ученых приходит в своих оценках налоговой реформы в недропользовании к выводу о том, что в России создана система налогообложения, которая не учитывает природные отличия продуктивности разрабатываемых месторождений и качество добываемого сырья.

Опыт применения данного налога (НДПИ) - использование одномерной ставки налогообложения добычи - отрицательно сказался на экономической эффективности организаций, разрабатывающих месторождения в районах традиционной добычи, запасы которых уже в значительной степени выработаны, например в Ставропольском и Краснодарском краях, Сахалинской области, Республике Татарстан, Республике Башкортостан и некоторых других регионах. Также за пределами экономических интересов добычи остаются трудноизвлекаемые запасы, месторождения, расположенные в экстремальных природных условиях, месторождения с выработанными высокопродуктивными залежами и обводненные запасы.

Налоговое единообразие в подходах к пользователям недр, без учета качества сырья и добывных возможностей месторождений, среди которых не существует подобия, порождает экономическое неравенство и создает предпосылки для банкротства или поглошения мелких и средних добывающих организаций крупными компаниями. Все это противоречит требованиям о комплексном и наиболее полном извлечении из недр невозобновляемого природного сырья.

Сторонники опоры на природную ренту фактически настаивают на полном изъятии у нефтяников рентной составляющей дохода и тем самым лишают отрасль, в которой работают сотни тысяч человек, возможностей развития. Ситуация, сложившаяся сегодня в нефтедобыче, показывает, что чрезмерное увеличение налоговой нагрузки на нефтяную отрасль в ущерб инвестициям не только не окажет сушественного влияния иа доходную часть консолидированного бюджета России, но и осложнит работу смежных отраслей российской промышленности (конец 80-х годов и первая половина 90-х годов прошлого века наглядный пример такого развития событий, когда, лишившись государственных инвестиций, государственная на тот момент нефтяная промышленность сократила добычу нефти на 40\%). 
«Сверхприбыль у нефтяников есть, но только на конкретно взятой скважине, - указывает заведуюший кафедрой горного права РГУ нефти и газа им. Губкина А.И. Перчик, - но из этого нельзя делать вывод об общей рентабельности отрасли. Говорить о том, избыточные это доходы или нормальные, можно только по конкретным месторождениям, а по компаниям в целом оценивать доходность с точки зрения справедливости платы за недра просто некорректно. Условия, в которых работают российские нефтяники и их зарубежные коллеги, совершенно несопоставимы... Плюс разница в погодно-климатических условиях Западной и Восточной Сибири и Персидского залива. Как после этого можно сравнивать налогообложение в столь разных странах?... ${ }^{15}$.

Итак, обычно выделяют абсолютную и дифференциальную горную ренту.

Дифференциальная горная рента I образуется на лучших и средних по условиям производства участках, где обеспечивается более высокая производительность труда за счет разработки месторождений, характеризуюшихся благоприятными природными факторами - качеством сырья, горно-геологическими условиями разработки, а также местоположением месторождений. Получаемая в результате этого добавочная прибыль и образует дифференциальную горную ренту, которая присваивается не разработчиком месторождения, а его владельцем.

Диффереипиальиая горная рента II образуется за счет применения более совершенной технологии добычи и переработки сырья, повышения удельной эффективности производства. Поэтому данная рента - следствие дополнительных вложений капитала. Понятно, что в этом случае дополнительный доход присваивает уже не собственник недр, а потратившийся предприниматель.

Абсолютиая горная рента представляет собой добавочную прибыль, получаемую владельием участка на любых, в том числе и на худших, месторождениях.

Монопольися горная рента получается с тех участков, где добываются редкие пли чрезвычайно необходимые потребителям природные ископаемые, которые продаются по монопольным ценам, определяемым лишь платежеспособностью потреб́ителей.

15 Цитировано по: Магвеев Ю.Ф., Субботии М.А. Рентный подход в педропользованин. М.: НИА-Природа, 2003. 244 с. С. 9. 
Налоговые правила сегодня таковы, что компании вынуждены сосредоточиться на наиболее рентабельных разработках, предельно ограничив стратегические инвестиции, лишая заделов не только себя, но и ТЭК в целом. Для сырьевого сектора любой экономики, и в частности для России и с ее огромным разнообразием месторождений проблема создания адекватного налогового режима в недропользовании является ключевой.

Сегодня для проведения полноценной инвестиционной политики в России жизненно необходимым становится создание надежной правовой среды, стимулирующей как иностранных, так и отечественных инвесторов к вложению капиталов в отечественную экономику. И необходимым элементом такой правовой системы должно стать концессионное законодательство. Напомним, что слово «концессия» в переводе с латинского означает разрешение или уступку: договор, заключаемый государством с частным предпринимателем; а лицензия (с того же латинского) - разрешение, право: разрешение на ведение того или иного вида деятельности. Как видим, понятия эти очень близки. И в том и в другом случае государство разрешает инвестору ведение дел в различных сферах экономики, но в первом случае - уступая ему часть своих функций, а в другом - давая право на выполнение определенных работ и услуг. Современная концессионная идеология восходит, в частности, и к Кодексу Наполеона, в соответствии с которым богатства недр, например, не должны принадлежать отдельным гражданам, а только государству на благо всех его граждан. Эта же правовая концепция нашла свое буквальное отражение в ст. $33 \mathrm{Koн-}$ ституции Индонезии 1945 г.: «Все природные богатства, находящиеся под землей и под водой, принадлежат государству и должны быть использованы для роста благосостояния народа». Не случайно именно индонезийское правительство в 1960-е гг. заключило первые соглашения о разделе продукции.

Концессии - старейшая из сушествующих форм соглашений между принимающим государством и инвестором в нефтедобыче. Гораздо позднее - в 60-х гг., появились соглашения о разделе продукции (СРП), еще позднее риск-сервисные контракты.

СРП - это никак не признак отсталости, а последняя по времени новаторская концессионная модель, адаптированная к инвестиционным условиям той или иной страны. Особый налоговый режим закона «О СРП» состоит из трех основных элементов: 
1) инвестор получает долю продукции в качестве возмещения затрат (п. 1 ст. 8 Ф3 «О СРП» называет ее компенсационной продукцией);

2) инвестор и государство делят продукцию, обозначенную как прибыльная (произведенная при выполнении соглашения продукция за вычетом части этой продукции, стоимостной эквивалент которой используется для уплаты налога на добычу полезных ископаемых, и компенсационной продукции за отчетный (налоговый) период) - ст. 8 Ф3 «О СРП»;

3) инвестор уплачивает государству налог на прибыль из своей доли прибыльной продукции.

Рентные платежи, а именно к таковым относятся арендные платежи в рамках СРП, позволяют учитывать индивидуальные условия каждого месторождения полезных ископаемых. Именно в рамках СРП изъятие природной ренты происходит наиболее аккуратным образом.

Многие страны СНГ и страны из бывшего социалистического лагеря имеют свое концессионное законодательство и успешно реализуют на практике проекты, заключив концессионные договоры. Подобные законы приняты в государствах СНГ (Казахстан, Кыргызстан, Молдова), Балтии (Литва, Эстония) и ближнего зарубежья (Венгрия, Болгария и др.).

Сегодня для проведения полноценной инвестиционной политики в России жизненно необходимым становится создание надежной правовой среды, стимулирующей как иностранных, так и отечественных инвесторов к вложению капитала в отечественную экономику. Необходимым элементом такой правовой системы должно стать концессионное законодательство.

Концессионное соглашение - это не просто контракт госпредприятия и частника типа договора аренды. Особенность данного вида соглашений состоит в том, что государство выступает сразу в двух ипостасях - как договаривающаяся сторона и как гарант соблюдения всех пунктов соглашения, включая предоставление гарантий неухудшения правовой среды при реализации соглашений. Никакой договор в рамках Гражданского кодекса таких гарантий дать не может.

При приватизации происходит поиск эффективного собственника, и собственность передается ему навсегда, при конщессионных соглашениях - поиск эффективного улравляюшего, когда определяется размер платежей и их структура, но собственность остается в руках государства. 
Минерально-сырьевой комплекс России вызывает устойчиво высокий интерес у потенциальных инвесторов. Однако процесс привлечения как отечественного, так и иностранного капитала идет весьма медленно и не соответствует ни реальным финансовым возможностям крупнейших международных компаний, ни потребностям российской экономики. Потенциальные инвесторы учитывают высокий уровень геологического, технологического, экологического и политических рисков в России. У инвесторов все еше нет твердых правовых гарантий и уверенности в стабильности инвестиционного режима ${ }^{16}$.

\section{Некоторые выводы:}

Законодательная практика государств, в том числе и России, идет по пути признания права собственности на минеральные ресурсы in situ. Международное право отрицает право собственности на такие ресурсы, допуская вешные права лишь на изъятые из места залегания полезные ископаемые.

Формы законодательного обеспечения института права собственности на минеральные ресурсы различны.

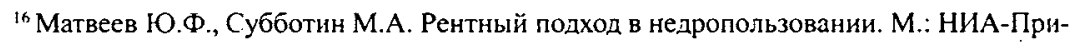
рода, 2003. $244 \mathrm{c}$. 